\title{
Researching the emerging impacts of open data: revisiting the ODDC conceptual framework
}

\author{
Tim Davies
}

Fernando Perini

\author{
University of Southampton, United Kingdom \\ Corresponding Author. \\ tim.davies@soton.ac.uk \\ International Development Research Center, \\ Canada \\ fperini@idrc.ca
}

This paper revisits the conceptual framework developed for the "Exploring the Emerging Impacts of Open Data in Developing Countries" (ODDC) research project. The framework was designed in 2012 to address persistent gaps in research and theory building around open data as an intervention that has been promoted for a broad range of reasons, from economic benefit, to bringing about greater transparency and accountability. The framework goes beyond a standard supply and demand model of open data, to look at how open data interacts with process of decision-making in a range of governance settings. We discuss how this framework can connect the critical study of open data with work on inclusion, innovation and accountability. The framework was applied between 2013 and 2015 in 17 in-depth case study projects on three continents. Through reflection workshops focused on the framework with case study authors, we identified the need for the framework to adapt to the development challenges where open data is to be applied, whilst identifying the value of the framework overall to support cross-case learning and theory building.

\section{Introduction}

Between the 2012 International Open Data Conference, hosted by the World Bank and the White House in Washington DC, and the 2015 edition of the conference, hosted in Ottawa, a lot changed in the world of open data. Whereas in 2012, conference panels were discussing

Davies, T., Perini. F. (2016). Researching the emerging impacts of open data: revisiting the ODCC conceptual framework. The Journal of Community Informatics, 12(2), (Special issue on Open Data for Social Change and Sustainable Development), 148-178.

Date submitted: 2015-12-13. Date accepted: 2016-06-20.

Copyright (C), 2016 (the authors as stated). Licensed under the Creative Commons AttributionNonCommercial-ShareAlike 2.5. Available at: www.ci-journal.net/index.php/ciej/article/view/1281 
the first few open data initiatives in developing countries (Majeed, 2012; Rahemtulla et al., 2011, 2012), by the 2015 conference, hundreds of participants, involved in open data initiatives on every continent, were participating. No longer a new or niche idea, the Open Data Barometer has found that the majority of countries surveyed have some form of official open government data efforts (Davies, 2013d; World Wide Web Foundation, 2015), and open data is amongst the most popular commitments made by countries in their Open Government Partnership National Action Plans (Foti, 2015; Global Integrity, 2012; Khan \& Foti, 2015).

Critical voices have been raised around the extent to which discussions of open data and a data revolution (Melamed, 2014) have come to dominate the agenda, displacing more nuanced discussions of open government and ICTs for development (McGee \& Edwards, 2016). However, claims that open data will bring about economic growth, improvements in democracy and better public services are still widely made, and carry weight (Carrara, Chan, Fischer, \& Steenbergen, 2015; Gurin \& Manley, 2015; Gurin, 2014; Hossain, Dwivedi, \& Rana, 2015). Few dispute that there are benefits to be gained from moving to an 'open by default' approach for government data (IODC Stewards, 2015), although the priority it should receive, and the approaches that should be taken, remain open questions.

Since open data first broke through onto the global stage with the launch of the US data.gov portal in 2009 (Lathrop \& Ruma, 2010), there has been an accumulation of research investigating the topic. Hundreds of papers, reports and articles have been published, yet until recently, sustained empirical work on the uses and impacts of open data has been scarce. Hossain et. al. (2015) review 96 papers from the peer-reviewed literature, finding a focus on organisational and inter-organisational research, with a particular emphasis on questions of policy design (Zuiderwijk \& Janssen, 2013), and drivers or barriers to open data initiatives successfully releasing data (Albano \& Reinhard, 2014; Conradie \& Choenni, 2012; Janssen, Charalabidis, \& Zuiderwijk, 2012; Martin, 2014; Martin et al., 2013). The bibliography compiled by members of the Open Data Research Network ${ }^{1}$ through an open Zotero group (available at http://bibliography.opendataresearch.org/) contains over 120 papers, the majority focusing on implementation of initiatives, and adopting either case study or interview methodologies.

Early research on open data in developing countries, and for development, was primarily conducted by outside researchers, either writing about how learning from developed countries might be transferred to development contexts (Hogge, 2010; Van den Broek, Rijken, \& Van Oort, 2012), or completing case studies of donor funded projects (Majeed, 2012; Rahemtulla et al., 2012). The framing of research was on new open data initiatives at the national level, rather than on how open data comes into contact with existing processes and challenges in countries. With increasing donor investment into open data interventions, and a paucity of research, there was a clear need for a deeper research programme.

It was against this background that in April 2012, the International Development Research Centre (IDRC), the World Wide Web Foundation and the Harvard Berkman Center for Internet and Society invited 30 open data and ICT for development experts from around the world to a workshop in Brasilia to develop a research agenda that would critically examine the impact of open data in developing countries (Perini, Davies \& Alonso, 2012). The initial

1 The Open Data Research Network is now part of the Open Data for Development (OD4D) network. 
development of the conceptual framework in this paper took place through that workshop. It was subsequently shaped through use within an open call for developing country led research into open data impacts (the Open Data in Developing Countries [ODDC] project), and its implementation by the researchers selected through that call.

The framework responded to a number of important gaps identified in 2012. There was almost no evidence published at the time on whether open data initiatives were delivering on their promises, particularly in developing countries. Reliable evidence on the outcomes and impact of open data initiatives was extremely scarce, and little was understood about how social and political context, open licenses, technical platforms and standards, and the dynamics of data use in different fields might affect potential outcomes and impacts. Furthermore, questions were already being raised about whether well intentioned initiatives might be resulting in adverse effects by exacerbating inequalities or negatively impacting existing governance structures (Gurstein, 2011; Lessig, 2009).

Although much progress has been made, in 2016, the refined framework still addresses a key gap. Many more reports, conference papers and journal papers looking at open data in developing countries are now available, but they frequently lack conceptual clarity (McGee $\&$ Edwards, 2016), and a common approach to describing the factors that may account for the success or failure of the open data interventions they describe. Without being clear on the nature of open data, the technologies employed, or the intermediaries active, building coherent practical and theoretical understandings of benefits, risks and relevant approaches to open data remains extremely challenging.

In the following section we introduce further background on the ODDC research project. We then introduce the initial conceptual framework, and ground it within wider literatures. The following section reflects on how it was applied across the ODDC case studies, before presenting the revised framework along with key learning from its application.

\section{Method: a collaborative research network}

The Exploring the Emerging Impacts of Open Data in Developing Countries project was funded by the Canadian International Development Research Centre (IDRC) and coordinated by the World Wide Web Foundation. The authors were involved as programme officer and research co-ordinator of the project respectively. Following the April 2012 expert workshop in Brasilia, inputs from a prior discussion paper (Heusser, 2012) were combined with workshop outputs (Perini, 2012) and a review of the literature to identify a set of core concepts for an open call for research proposals.

The open call, issued in July 20122, invited research teams led by developing country researchers, to provide short abstracts, research objectives and proposed methods for a yearlong research project. The call suggested a number of themes for potential cases, including.

Over 90 proposals were received, although ultimately focussing on a narrower set of categories than the call had anticipated. Proposals were reviewed and shortlisted at a workshop at Harvard University in October 2012. Shortlisted proposals were paired with a

2 Available at http://public.webfoundation.org/2012/07/ODR-CfP.html 
research mentor, drawn predominantly from the experts who participated in the original workshop, and were invited to use the draft conceptual framework to plan their research in more detail. Final research plans were confirmed, and projects funded. Seventeen cases were selected overall. Selected researchers included participants from NGOs, private consultancies and academic institutions, working in a wide range of settings. These were organised into four initial thematic clusters as shown in Table 1, drawing on the conceptual framework's identification of particular kinds of data, mechanisms of governance and forms of impact.

Table 1: Case studies clusters

\begin{tabular}{|c|c|}
\hline Budget transparency \& governance & Urban Governance \\
\hline $\begin{array}{l}\text { Public Expenditure Data }>\text { Public Resources / } \\
\text { Budgets > Transparency and accountability } \\
\text { An Investigation of the use of the Online } \\
\text { National Budget of Nigeria by Relevant } \\
\text { Stakeholders (University of Ilorin, Nigeria) } \\
\text { Exploring the emerging impacts of open aid } \\
\text { data and open budget data in Nepal (Freedom } \\
\text { Forum, Nepal) } \\
\text { Measuring open data's impact of Brazilian } \\
\text { national and sub-national budget transparency } \\
\text { websites and its impact on people's rights, } \\
\text { especially people living in poverty (Institute for } \\
\text { Socioeconomic Studies, Brazil) } \\
\text { Case Study on Open Data Initiative of Ministry } \\
\text { of Finance on National Budget Transparency in } \\
\text { Indonesia (Sinergantara, Indonesia) }\end{array}$ & $\begin{array}{l}\text { Public service data }>\text { Urban governance }>\text { More } \\
\text { efficient, innovative and inclusive service delivery } \\
\text { Opening the Cities: Open Government Data in Local } \\
\text { Governments of Argentina, Brazil and Uruguay } \\
\text { (Brazil) } \\
\text { Opening Government Data by Mediation: Exploring } \\
\text { the Roles, Practices and Strategies of Data } \\
\text { Intermediary Organizations in India (India) } \\
\text { Quality of civic data in India and the implications on } \\
\text { the push for Open Data (Transparent Chennai, India) } \\
\text { Opening the Gates: Will Open Data Initiatives Make } \\
\text { Local Governments in the Philippines More } \\
\text { Transparent? (Step Up Consulting Services, The } \\
\text { Philippines) } \\
\text { Open Government in the Philippines: Exploring the } \\
\text { role of Open Government Data (OGD) and the use } \\
\text { new technologies in the delivery of public services (De } \\
\text { La Salle University, Manila, Philippines) }\end{array}$ \\
\hline Poverty alleviation & Emerging issues \\
\hline $\begin{array}{l}\text { Various data }>\text { Urban and rural poverty }> \\
\text { Inclusion and empowerment }\end{array}$ & $\begin{array}{l}\text { Various data }>\text { Various governance settings }>\text { Various } \\
\text { outcomes }\end{array}$ \\
\hline $\begin{array}{l}\text { Exploring the impacts of budgetary information } \\
\text { web publishing in the subnational level of Brazil } \\
\text { (Research Group on Public Policies for } \\
\text { Information Access, Brazil) }\end{array}$ & $\begin{array}{l}\text { Open Data in the Judicial Systems: Evaluating } \\
\text { Emerging Impact on Policy Design in Paraguay, } \\
\text { Chile and Argentina (Center of Implementation of } \\
\text { Public Policies for the Equity and the Growth, } \\
\text { Argentina) }\end{array}$ \\
\hline $\begin{array}{l}\text { Investigating the Impact of Kenya's Open Data } \\
\text { Initiative on Marginalised Communities: Case } \\
\text { Study of Urban Slums and Rural Settlements } \\
\text { (Jesuit Hakimani Trust, Kenya) }\end{array}$ & $\begin{array}{l}\text { The use of open data in the governance of South } \\
\text { African higher education (University of Cape Town, } \\
\text { South Africa) }\end{array}$ \\
\hline $\begin{array}{l}\text { A Monitoring And Evaluation Study on the } \\
\text { Deployment of Code4Kenya Applications and } \\
\text { Services (iHub, Kenya) }\end{array}$ & $\begin{array}{l}\text { Open government data for regulation of resource } \\
\text { intensive energy industries in India (The Energy and } \\
\text { Resources Institute, India) }\end{array}$ \\
\hline $\begin{array}{l}\text { How could open data contribute to poverty } \\
\text { eradication in Kenya and Uganda through its } \\
\text { impacts on resource allocation? (Development, } \\
\text { Research and Training, Uganda) }\end{array}$ & $\begin{array}{l}\text { Taking Stock of the Effectiveness and Efficiency } \\
\text { Initiatives in Sierra Leone (Society for Democratic } \\
\text { Initiatives, Sierra Leone) }\end{array}$ \\
\hline
\end{tabular}


Research leads from each case were invited to a launch workshop in London in April 2013 where the conceptual framework was discussed, and participants explored different methodological tools that could be paired with particular components of the research framework (Davies, 2013a). Over 2013 and early 2014, researchers worked on their case studies, meeting together in a number of regional and thematic clusters to share early findings, taking part in regular web-meetings and working with research mentors. Most mentors were working with more than one case, supporting cross-case learning. This intensive engagement between cases, and between the case researchers and the research coordinator contributed to on-going development of the conceptual framework and associated methodological tools.

At the end of the case study research phase, participants convened for a final workshop in Berlin, alongside the 2014 Open Knowledge Festival. This workshop provided a change to present final findings (Davies, 2014a), and to reflect together on the conceptual framework. During this discussion a number of amendments to the framework were proposed, which are discussed below. An independent evaluation of the first year of the programme further contributed to reflection on the conceptual framework and its translation into common methodological tools within a diverse mixed-methods network.

\section{Differentiating open data: beyond supply and demand}

In this section we describe the core of the conceptual framework, and how it was developed in response to a number of limitations in prior approaches to the study of open data.

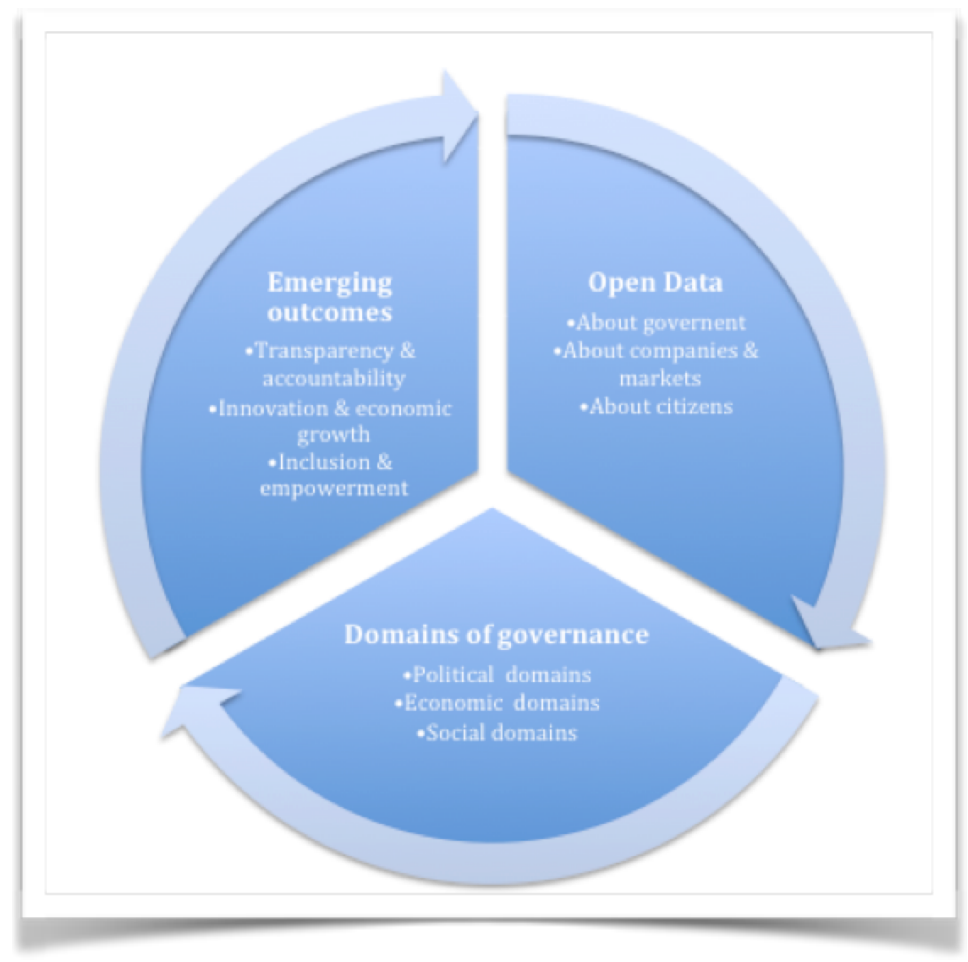

Figure 1: A framework for differentiating open data 
One of the persistent challenges in open data research has been a tendency to conflate different kinds of data, different mechanisms of change, and different kinds of impact. A starting point for our conceptual framework comes in drawing distinctions in each of these areas, calling for clarity that can support comparison across cases.

Figure 1 was developed based on a synthesis of discussion at the initial project workshop (Perini et al., 2012), identifying the importance of looking at interactions between the source of data, the 'domain of governance' it is used within and the mechanism through which outcomes may be secured.

\section{Open Data: sources and openness}

The first distinction here, on the source of data, responds to the tendency of literature to focus solely on open government data (OGD), defining the object of study as 'data from government' that meets the Open Definition (Open Knowledge Foundation, 2014). There is an embedded assumption here, generally more warranted in developed over developing countries, that the kinds of data that might be used to deliver on the promise of open data will be held by governments. Whilst strong and well-resourced states may have historically played an important role as nodal powers, with a monopoly on comprehensive data collection (Agar, 2003; Hood \& Margetts, 2007), in developing countries a wide range of government, NGOs, international agency and private actors may be involved creating and holding relevant data. Drawing on Fung and Weil's (2010) call for a focus not only on 'open government' but also 'open society', in which private sector actors may be encouraged to disclose data alongside the state, we identified three kinds of data: (1) Data about governments; (2) Data about companies and markets; and (3) Data about citizens.

The last category here also offered a chance to draw attention to emerging privacy concerns (Davies, 2013b; Floridi, 2014; Kulk \& Van Loenen, 2012; Scassa, 2014). Whilst data describing the actions of the state may be relatively uncontroversial to publish, data about citizens, even aggregated, may need more sensitive handling. Wright et al. (2011) had drawn attention in particular to the issue of community rights in India as a concern that should give pause before individualist data protection regimes from European or US experiences were simply adopted as a general feature of open data policy.

In 2012, although one the biggest developing country open data investments to date had been into the Kenya Open Data Portal (Rahemtulla et al., 2011), few developing countries had substantial open data portals. The temptation to focus on the data published on government portals, and to restrict an assessment of open data to this particular supply, has been common in the literature (Atz, Heath, \& Fawcett, 2015; Wolrd Resources Institute, 2012; Reiche, Höfig, \& Schieferdecker, 2014; Veljković, Bogdanović-Dinić, \& Stoimenov, 2014). However, this misses out on identifying the wealth of datasets that institutions in developing countries are providing and accessing through other sources. Whether or not portals effectively support impacts of open data should remain, in our view, an open question, and any conceptual framework should allow this to be addressed. 


\section{Governance: using data for taking decisions}

In framing the focus of our research work, we looked not at 'open government data', but instead at open data used for decision-making in distributed governance settings. The focus on governance incorporates recognition that decision-making is a multi-layered process, increasingly taking place through networks (Dunleavy, Margetts, Bastow, \& Tinkler, 2006) and taking new institutional forms. It is important that any investigation of the effects of open data is sensitive to the way in which opening up data reconfigures governance relationships which include many actors including government officials, national statistics offices (NSOs), media, researchers and citizens (Huber \& Maier-Rabler, 2012), as well as affecting existing processes of formal decision-making and implementation.

To further explore the question of how open data changes decision-making, we need to understand different ways to frame decisions. In other words, we need to understand whether we are exploring political, economic and social domains. The political domain is one of political power in given territories, elections, checks and balances, budget setting and expenditure monitoring. The economic domain involves market mechanisms, trade, exchange and innovation. And the social domain involves the diverse activities of civil society, formal and informal institutions and self-organising communities. This context influences the analysis and claims made for the potential impact of open data.

In order to understand the decision-making process, it is key to be explicit in relation to the specific (and sometimes, distributed) governance setting where decisions are made. Some of the specific governance settings that were identified and highlighted in the open call include: local and national budgeting processes, legislative processes and elections, judicial systems, smarter cities, delivery of public services, science and technology, regulation of markets (e.g. extractive industries), welfare and empowerment of marginalised groups and communities (e.g. smallholder farmers), and international development.

Table 2 shows how it is possible to identify different 'theories of change' in each of the three domains, as well as hypothesise about how open data might affect a specific governance setting. It is important to notice that the different domains involve decisions with substantially different configurations of actors, issues and disciplinary perspectives. It is also important to understand in detail the specific governance setting in order to theorise how an open data intervention will change decisions and have greater impact.

Table 2 - Governance settings and specific theories of change on the impact of open data

\begin{tabular}{|l|l|l|}
\hline Domains & $\begin{array}{l}\text { Examples of theory of change in different } \\
\text { governance settings }\end{array}$ & $\begin{array}{l}\text { Key disciplinary } \\
\text { traditions/Streams }\end{array}$ \\
\hline Political & $\begin{array}{l}\text { Open budget data will bring about greater } \\
\text { transparency in government, which in turn brings } \\
\text { about greater accountability of key actors to make } \\
\text { decisions and apply rules in the public interest. }\end{array}$ & $\begin{array}{l}\text { Political science, public } \\
\text { administration, legal studies }\end{array}$ \\
\hline Economic & $\begin{array}{l}\text { Open transport data will enable non-state innovators } \\
\text { to improve public services or build innovative } \\
\text { products and services with social and economic value. }\end{array}$ & $\begin{array}{l}\text { Economics, business } \\
\text { models, regulation }\end{array}$ \\
\hline
\end{tabular}


Social

Open census data will remove power imbalances that Social science, community resulted from asymmetric information, giving informatics

marginalised groups a greater say in key policy debates.

In the following section we further explore some of these theories of change, and survey the existing literature on areas where emerging impacts of open data may be observed.

\section{Emerging outcomes}

In our initial project workshop (Perini et al., 2012) and from an analysis of the literature, we identified three broad categories that capture the mechanisms through which commentators have suggested open data creates impact. These were:

(1) Transparency and accountability: open data will bring about greater transparency, which in turn brings about greater accountability of key actors, leading to them making decisions and applying rules in the public interest;

(2) Innovation and economic development: open data will enable non-state innovators to improve public services or build new products and services with social and economic value; open data will shift certain decision making from the state into the market; and

(3) Inclusion and empowerment: open data will remove power imbalances that resulted from asymmetric information, and will bring new stakeholders into policy debates, giving marginalised groups a greater say in the creation and application of rules and policy.

Subsequently, our attention has been drawn to the omission of an explicit reference to internal government reforms from this framework. Open data can be used to drive internal efficiencies, or support government-led innovation as well as innovation from outside the state (Dos Santos Brito, Da Silva Costa, Garcia, \& De Lemos Meira, 2014; Gerunov, 2015; Roy, 2014; Srimarga et al., 2014). This could be incorporated into the framework through the addition of a new term for 'government reform'. This is particularly important to programmes such as Making All Voices Count, which focus on 'active citizenship and government responsiveness', and for which understanding the role of open data in maintaining a balance between government capacity and citizen power is important (McGee, Edwards, Minkley, Pegus, \& Brock, 2015). We prefer, however, to revise the second term to incorporate government reform - whilst maintaining the recognition that many accounts draw heavily on the idea of introducing ideas from the market into government to deliver this change (O’Reilly, 2010; Robinson, Yu, Zeller, \& Felten, 2009) updating it as:

- Innovation, economic development and efficiency: open data will enable innovators to improve public services or build new products and services with social and economic value; open data will shift the location of decision-making and decisionmaking power, including increasing use of market mechanisms.

We also note that this component of our framework was initially labelled 'emerging impacts' but later changed to 'emerging outcomes' as we explored the important limitation of case study research in establishing robust proof of impact. In many ways, transparency and accountability, innovation, or empowerment, could all be regarded as only means to ends: as 
methods to achieve some good outcome rather than the outcome themselves. However, in practice they play a dual role: both authors and activists to tend to desire transparency or inclusion as a good in itself, recognising it may only be a stepping-stone to securing justice more broadly, but understanding it as a vital stepping-stone none-the-less.

As methods to achieve change, these emerging outcomes are not mutually exclusive. In any governance setting one might find different routes being explored by different actors -for example, one group might choose to use open data on public transport to hold existing service providers to account (transparency and accountability), whilst others may use the data to build commercial mobile applications that help travellers to find the fastest route, or check on the times of buses and trains (innovation and economic development). Understanding that the same data could be used in multiple ways, through very different emerging outcome mechanisms, makes it possible to ask whether a particular configuration of how the data is supplied leads to one method of change being easier to pursue than another.

\section{Beyond supply and demand}

Open data research has commonly followed a linear path, starting from assessing the capability of countries to supply data (APC \& CIPESA, 2012; Grewal, Iglesias, Alonso, Boyera, \& Bratt, 2011; Iglesias, 2011), and then turning, eventually, to questions of demand for, and use of, data. This leads to a focus on interventions that can either improve data quality, or stimulate data demand through events such as hackathons, app competitions and data bootcamps (Boyera \& Iglesias, 2014; Kuk \& Davies, 2011; Shemie et al., 2012), or data journalism training (Gray, Chambers, \& Bounegru, 2012).

However, by organising our conceptual framework as a cycle, we suggest that the research process can start at any point: not just from the supply of data. Instead, it should be possible to identify particular governance challenges, and then look at the kinds of interventions actors are pursuing to address them, such as promoting transparency, before turning to identify datasets that are being used.

This escape from a linear supply and demand research focus was captured in the ODDC call for proposals that asked potential researchers to start from identified governance situations. It was reinforced by asking for the identification of specific datasets implicated in addressing governance challenges in this setting. Understanding the impacts of open data requires attention to the features of specific contextualised data (Gitelman, 2013), and cannot be realised by abstract study of 'data in general'. Furthermore, with specific change mechanisms identified, it becomes possible to link open data into wider debates about governance, and social and economic change.

The following section presents a literature review developed to ground the investigation of emerging outcomes of open data in contemporary debates.

\section{Emerging outcomes in focus}

McGee and Edwards (2016) have recently commented on the lack of conceptual clarity in the 'open government' space. The same can be said of the broader open data literature, where broad categories of 'transparency and accountability', 'innovation, economic development 
and efficiency' and 'inclusion and empowerment' hide many more specific definitional issues. This section offers a non-exhaustive survey of some of the key issues to consider when operationalising these terms.

\section{Transparency and accountability}

Although transparency and accountability are frequently discussed together, they are distinct concepts. The pairing has become a mainstay of governance, where deficits of accountability can leave those in power able to practice corruptly, and to serve their own, rather than the public interest. Transparency is an essential ingredient for accountability (Joshi, 2012), but is rarely a sufficient condition for it (Fox, 2007; Kuriyan, Bailur, Gigler, \& Park, 2012). Accountability involves the capacity to 'elicit justification, render judgment and impose sanctions' on those with power (Joshi, 2012, p. 4). Whilst accountability relationships may be established internally to government by key stakeholders in a governance system such as when an audit institution demands to see the financial records of a government department, or when a public commissioner of road building orders an inspection of build quality and calls in the contractor to explain discrepancies between the specification and delivery, in the context of open data the pairing of transparency and accountability suggests a focus on allowing external actors, citizens in particular, to play a role in holding power to account. In Heald's (2006) terminology this is the distinction between 'horizontal' and 'upwards' transparency, and 'downward' transparency "when the "ruled" can observe the conduct, behaviour, and/or "results" of their "rulers" (ibid.).

Whilst states have long demanded upwards transparency from other parts of society in order to enforce regulations, Fung et al. (2007) note that over recent decades governments have also adopted 'targeted transparency' policies, in which they require firms to open up information or data on their products or actions to consumers in order to change firm and consumer behavior. For example, the publication of food safety or pollution information. Fung et al. (2007) go on to suggest that a third wave of transparency is emerging, in which citizens do not need to wait for government policies, but can instead remix openly available data to generate pressure on firms for change, more aligned with citizen interest. However, they also note the limitations on the effectiveness of targeted transparency, noting that such approaches work best when: 'A bridgeable information gap contributes substantially to risks or public service failures [...] The policy problem lends itself to consensus metrics [...] Communication is practical [...] Information users have the will, capacity, and cognitive tools to improve their choices [...] Information disclosers have the capacity to reduce risks or improve performance [...and] Variable results are acceptable' (Fung et al., 2007, p. 175).

In both open government data, and new data-driven forms of targeted transparency, the focus is placed on proactive disclosures. A contrast can be drawn here reactive transparency practices as invoked in right to information (RTI) laws where citizens are entitled to request information from government, usually in documentary rather than data forms (Janssen, 2012; Open Knowledge Foundation, 2011). Some moves towards linking open data into reactive transparency have taken place in the United Kingdom, where amendments to the national Freedom of Information Act provided a 'right to data' allowing citizens to request structured datasets (HM Government, 2012b), although there is little evidence of this having been widely used. 
The extent to which differences and tensions between activists working on open data and RTI can be traced to substantial differences in their aims and methods, or instead is driven by particular historical circumstances of the movements, was a recurring question for members of the ODDC network, a number of whom addressed this in their work to propose greater synthesis between the movements in Sierra Leone, Nepal and worldwide (Abdulai, 2014; Fumega, 2015; Sapkota, 2014).

The important point to keep in mind, and often elided in open data literatures, is that open data is not directly identical to transparency. Heald (2006), amongst others, argues '[o]penness might [...] be thought of as a characteristic of the organization, whereas transparency also requires external receptors capable of processing the information made available' (Heald, 2006 quoting Larsson, 1998). A related point has been made by Gurstein (2011), noting that having data online under open licenses does not mean that everyone has effective access or can make 'effective use' of the data. Citizens may face barriers of technology, literacy, education or social capital that prevent them effectively receiving and processing information that might have been made available (Gurstein, 2011). The way in which data is published, the context it is put in, the support on offer to enable access and use, and the presence of intermediaries, all affect how far open data will lead to increased transparency.

Where open data has led to greater transparency, another set of intervening relationships may determine how far it leads to accountability. In a collection of essays on corruption and democracy in Brazil (Power \& Taylor, 2011), authors highlighted a range of accountability channels, from the ballot box, to audit institutions, media coverage, judicial action and police enforcement. Transparency has the potential to enable new accountability channels, and to affect the operation of existing channels. For example, the use of open data in data journalism has the potential to strengthen the capacity of existing media to hold government to account, and to support the emergence of new media players (Fink \& Anderson, 2014; Howard, 2014; Martinisi, 2013). Similarly, government ministers in the UK heralded the potential for an 'army of armchair auditors' to emerge using public spending data to hold government to account (Maguire, 2011; McClean, 2011; Worthy, 2013) (individual citizens taking on the role of reviewing government spending from the comfort of their own computers), whereas Speck (2011) notes that in the Brazilian case transparency can help actors outside government place issues on the agenda of the formal audit institutions, affecting how they operate, but neither bypassing nor replacing the need for formally instituted audit.

In the April 2012 workshop participants particularly highlighted how public availability of data could empower 'good' civil servants to oppose corrupt practices within their institutions without having to turn directly to whistleblowing (Perini et al., 2012): in this sense, transparency and accountability is also an enabler of internal government reform. It is possible also that transparency creates more 'accountable' behaviour without the need for actual accountability mechanisms to be exercised, as when knowing information on their actions will be made public, and that indiscretion could be discovered encourages officials to behave better (Meijer, 2007). However, Fox cautions that 'If the power of transparency is based on the "power of shame", then its influence over the really shameless could be quite limited' (Fox, 2007, p. 665). 
Against the widespread optimism about transparency, the literature also highlights the possibility of adverse effects from greater transparency, as more openness can create perverse incentives, limit space for free discussion in politics, lead to 'gaming' of the data, can contribute to surveillance of citizens by the state, or can shift power to distant institutions rather than to citizens (Ballingall, 2011; Heald, 2006, 2011; Lessig, 2009; Murray, 2011). These effects depend both upon the design of the transparency intervention, and the wider political context in which it takes place.

In approaching transparency and accountability arguments for open data, it is important to pick apart each of the terms: open data, transparency and accountability, to understand each as separate stages of a process to be analysed, and each affected by a range of factors. Since 2012, research in technology for transparency and accountability has developed apace. However, little analysis has yet achieved the conceptual clarity that McGee and Edwards (2016) call for, and there is a tendency for conclusions to either focus on the need for better technology, or better political analysis, but without offering an account that crosses between the two, showing how the politics and technology of transparency and accountability are, in practice, co-constituted in any particular case.

\section{Innovation, economic development and efficiency}

Open data has been described as 'digital fuel of the 21st century' (Kundra, 2012), a raw material that can support new economic activity and lead to dramatic breakthrough innovations. Arguments concerning the economic potential of government data were key drivers for open data initiatives, particularly in the EU, where many studies argued that billions of dollars in potential economic activity were being lost through the ways governments managed their data, either not providing any at all, or providing it for a fee (Dekkers, Poleman, Te Velde, \& De Vries, 2006; Newbery, Bently, \& Pollock, 2008; Pollock, 2009; Uhlir, 2009). Whilst some of this economic value may come from large-scale public sector information (PSI) re-user firms creating products with government data, such as maps or improved weather reports, many advocates of open data have focussed on the potential for open data to be used by small and medium enterprises (SMEs), predominantly in the technology sector, to create new products or find new niche markets (Fioretti, 2010), tapping into the 'long tail' of government data and market needs (Anderson, 2006), and opening up opportunities for more inclusive models of economic growth.

The release of open government data to stimulate domestic technology industries, and the creation of new 'start up' firms was a strategy evident by 2012 in the UK (HM Government, 2012a), Kenya (World Bank, 2012) and US (Kundra, 2012) open data initiatives, and it remains a high policy priority (Stott, 2014). However, one of the most widely cited estimates of the economic gains to be had from moves towards open data is notable in attributing most of the value to developed countries. Manyika et al. (2013) estimate that 'the potential value would be divided roughly between the United States (USD1.1 trillion), Europe (USD900 billion) and the rest of the world (USD1.7 trillion)'. Distribution of benefits from open data remains an important topic. One particular theme emerging in ODDC case study research in Nepal was how countries were concerned about the economic returns on national government data being secured by neighbouring countries with much more developed ICT industries (Sapkota, 2014). 
Governments may also release open data to stimulate innovation in the delivery of public services, both through external innovation and internal efficiency. Open government data initiatives have often been linked to Tim O'Reilly's notion of 'government as a platform' (O'Reilly, 2010) in which government acts as a provider of data upon which dynamic entrepreneurial actors outside the state can innovate to provide better, more efficient or more customised public services. This taps into an argument about the greater innovative capacity of the private over the public sector, ideas of user and open innovation (Von Hippel \& Von Krogh, 2009; Von Hippel, 2005), and the view that both commercial and not-for-profit enterprise can act as intermediaries delivering public service (Mayo \& Steinberg, 2007). The widely cited 2008 'Apps for Democracy' contest by the United States District of Columbia has suggested that through awarding just USD50,000 in prizes in an apps contest, developers outside the government put together 47 applications that would have cost USD2.6m if developed internally (United Nations, 2010) although some have raised questions about the sustainability and actual realisation of this value (Nichols, 2010).

In seeking to secure some of the innovation and co-production benefits of open data the Kenya Open Data Initiative had an early focus on steps to create an 'ecosystem', connecting data providers in government with entrepreneurs and ICT trained young adults (World Bank, 2012). This suggests the hypothesis that enabling open data to drive public and private sector innovation requires more than datasets alone. Understanding the conditions that are conducive to data-enabled innovation, and the kinds of policies that can promote it, is an important area for research. This requires attention to both the micro-level of conditions around particular datasets (for example, whether or not a transport ministry or agency is ready to collaborate with developers from outside government to work on co-producing services), at the mid-level (for example, whether government procurement policies allow it to engage with and appropriate innovative public service ideas from SMEs), and at the macrolevel (for example, whether national policies and infrastructure support tech sector innovation). Equally, critical research is needed to assess how far open data enabled innovation serves widespread social needs, or is only able to deal with certain kinds of problems.

Open data has a further potential role within the sphere of economic development - as a resource for the more effective and equitable functioning of markets. All markets require some form of oversight and regulation - yet markets are increasingly complex and hard to monitor. Both citizens and regulators face severe challenges in exercising effective oversight in many sectors, and it has been suggested that open data can play a role here. For example, the Extractive Industries Transparency Initiative, designed to support monitoring of extractives markets, have developed a common data standard to assist monitoring of contracts (EITI International Secretariat, 2012); and the OpenCorporates.com project that has collated open data on millions of companies around the world has been actively participating in the EU Financial Stability Board (Taggart, 2012) promoting the use of open data to enhance oversight of the markets implicated in the 2009 financial crash. New data infrastructures are being proposed to address issues of tax transparency, and to help combat illicit financial flows (Gray \& Davies, 2015), recognising the importance of making connections between distinct market-governance related datasets in order to build up a more complete picture of economic activities, and to support oversight of complex corporate activities. 
Although economic potential has been a key driver for the progress of a global open data agenda, there remain many unanswered questions on both the macro-economic and microeconomic effects created by particular features of an open data initiative, from choices of standards to licenses adopted. From a development perspective, constant attention to the distribution of economic benefits remains vital.

\section{Inclusion and empowerment}

Canada's International Development Research Centre (IDRC) has championed a number of research networks under the banner of 'open development'. Different projects covered topics from open access, and open educational resources, to open science, open innovation, and open data (Smith \& Reilly, 2013a; Smith, 2015). Central to the open development concept is the idea of a relationship between the openness of content (such as datasets), openness to people (in terms of the diversity of participants who can actively collaborate), and openness of process (in terms of transparency, and contingency) (Smith \& Reilly, 2013b). Bentley and Chib (2016) find three primary narratives within open development:

1) that digitally-enabled openness provides greater access and can potentially enable greater inclusion of poor and marginalized people and perspectives; 2) that the decentralized nature of open models can potentially redistribute power and result in more efficient and effective collaboration outcomes; and 3) that the emergence of open phenomena is constituting a new form of development all together (Bentley \& Chib, 2016, p. 3).

These narratives are central to the articulation of the inclusion and empowerment potential of open data: calling for an exploration of how shifts in the technical and legal openness of datasets might impact the diversity of individuals able to access the political, social and economic processes they relate to, and might reconfigure power relations.

Within the economic domain, ideas of inclusion and empowerment may relate to whether or not actors currently kept outside of the financial mainstream are able to benefit from open data. The distribution of economic benefits is covered in the next section.

Within the domain of political and social governance, this idea of inclusion and empowerment can be found within the idea that opening up access to data could help to address asymmetries of information between companies and officials and citizens, NGOs and grassroots groups (Davies, 2010). With open data, the argument runs, there is the possibility for local communities to build up their own understandings and interpretations of key issues, and for intermediaries to contextualise information in ways that make sense to diverse groups, including citizens at the grassroots. Through print-outs, mobile phone-based services, offline access, community radio, and participatory workshops (De Boer et al., 2012; Lee, 2014) data can be taken to local settings - empowering previously marginalised groups, and can provide the basis for feedback loops that enable local communities to shape the knowledge base on which policies are based (Custer, 2012; Gigler, Custer, \& Bailur, 2014; Srinivasan, 2012). However, as Gurstein (2011) has noted, open data alone does not necessarily equate to empowerment, and there is a risk that a 'data divide' is created, where data only empowers the already empowered (Gurstein, 2011). 
Whilst evidence from the UK suggests that open data has engaged a number of new actors in thinking about public services and governance (Davies, 2010), little work could be identified in 2012 that had mapped out the users of specific open data, and explored how far open data was supporting greater inclusion in policy making and governance processes. Subsequent work exploring the profile of users of other forms of ICT-enabled governance tools has pointed to a bias towards well-educated and middle class users being the main beneficiaries although with some broadening of the pool beyond those who were already engaged prior to ICTs being introduced (e.g. Rumbul, 2015). Bentley and Chib (2016) are particularly critical of the lack of inclusion focus in the open development research agenda, stating in a review of the literature that ' $[\mathrm{w}] \mathrm{e}$ found very little evidence that research within this area is concerned with the perspectives of poor and marginalized people - notably women'.

In digging deeper into the limited evidence base for inclusion impacts of open data there is an important distinction to draw between inclusion which treats marginalised groups as objects of development, and that which directly engages marginalise groups. In a direct process, open data is used to empower individuals and groups as active participants in the development process (Perini et al., 2012; Powell, Davies, \& Taylor, 2012), shaping it around their own needs, and making claims in their own right. In an indirect process, data might be used to better plan and co-ordinate services for marginalised groups as the beneficiaries, bringing some increase in welfare, but without promoting the voice and influence of those groups.

The literature since 2012 has placed particular emphasis on the influence of open data intermediaries (Chattapadhyay, 2014; Dumpawar, 2015; Magalhaes, Roseira, \& Strover, 2013; Rojas, 2012; Van Schalkwyk, Willmers, \& McNaughton, 2015; Van Schalkwyk, Canares, Chattapadhyay, \& Andrason, 2015). Frank and Waddell (2014) discuss the range of roles they may play from simply facilitating access to data, through to actively 'coordinating and moderating deliberation, and processing the results of the deliberation', placing predominantly technically skilled actors in positions of considerable power. Moss and Coleman (2014) suggest that 'important questions remain concerning [...] how intermediaries (some of which may be pursuing particular interests and agendas) frame and analyse data on behalf of citizens'.

Tygel et al. (2015) have developed an account of 'interpretation autonomy', exploring the kinds of skills that citizens need in order to have the freedom to access and interpret data in the ways they choose, securing the kinds of 'open process' envisioned by open development theory. Greater autonomy comes from use of richer data and more flexible software tools, but this requires a greater investment in capacity building, or existing stocks of technical skill and data literacy. Whilst some elements of autonomy can be promoted through more intuitive tools, the need for either advanced capabilities or mediation to work with data cannot be escaped.

There is also an important distinction to be drawn between individual and community empowerment effects of open data. For example, Bates (2012) argues that the UK open data agenda has developed to support the marketisation of public services, in which citizens are cast as consumers, offered data to help them make individual choices, but in which the potential of collective action to secure social provision of appropriate public services may be side-lined (Bates, 2012). This could be seen as a running counter to the shift Cornwall and Gaventa (2001) see in development 'from a focus on clients or consumers of social policies 
as users and choosers to a more active engagement of citizens as agents in the making and shaping of the social policies that affect their lives' (Cornwall \& Gaventa, 2001, p. 5). Understanding the conditions under which open data can be used to enable not existing elites, but rather marginalised groups, to become makers and shapers is a vital part of a developmental open data research agenda.

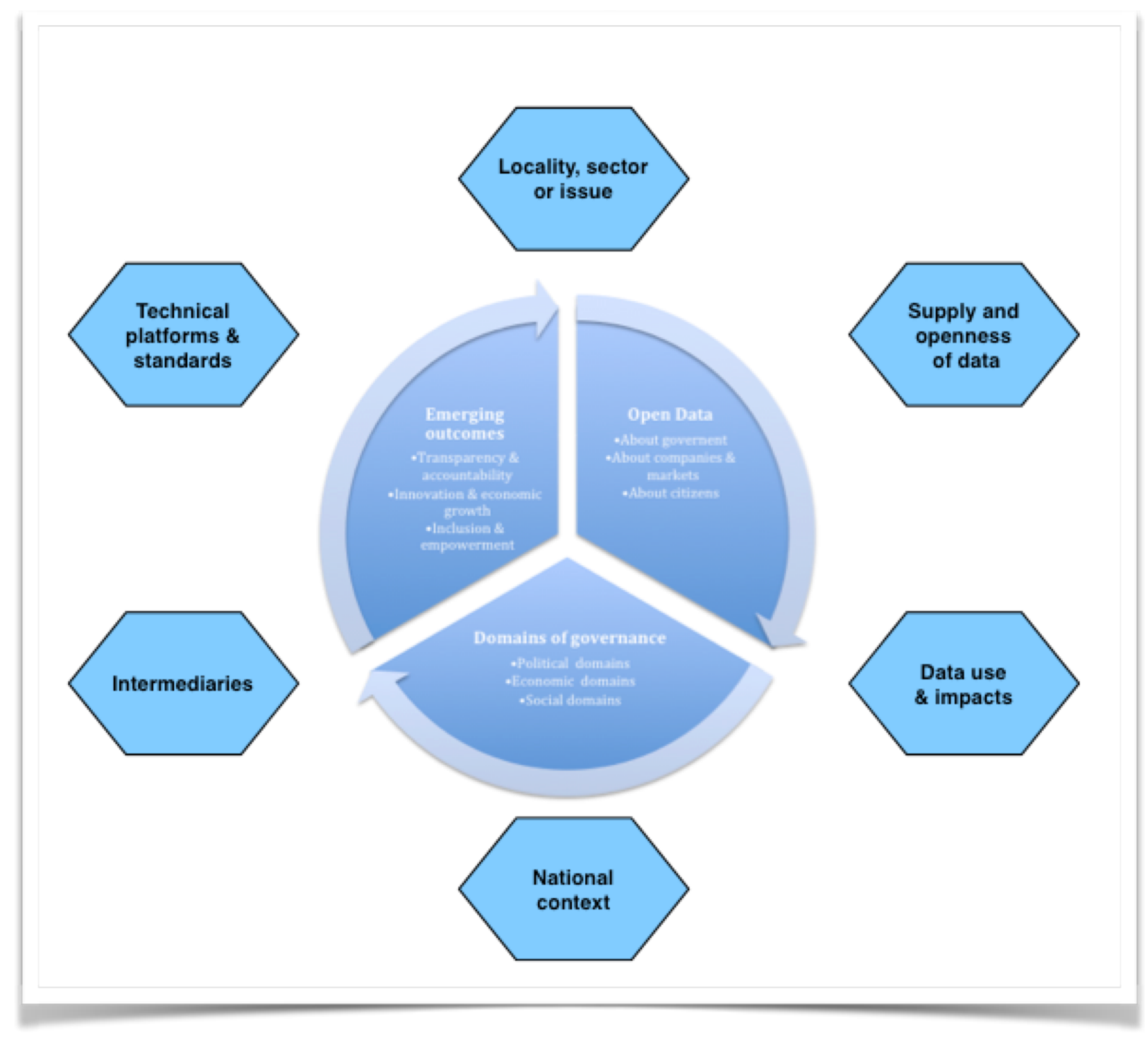

Figure 2: Research framework and case study components (2014 revised version)

In the standard linear supply and demand model of open data, inclusion and empowerment impacts of open data are often seen as occurring far down the 'value chain', after a number of intermediate steps. The kinds of individual claim-making empowerment outcomes from open data that Davies (2010) documents are also frequently invisible within the wider open data landscape, with those who happen to find the information they need to empower them in their interactions with the state not overly concerned with whether or not it originated as open data, and thus not able to articulate their case as open-data enabled. This underscores the importance of a wider conceptual framework which supports investigation of demand-driven open data projects: cases where communities have sought out data, as well as cases where 
governance institutions have proactively published. Such cases also allow the effectives of proactive publication to be disentangled from the effects of open technical and legal regimes around a dataset.

\section{Research in practice: a case study toolkit}

In this section we introduce an additional component of the framework in the form of six case study components which were iteratively developed in order to operationalize research into key areas identified above, and to support cross-case comparisons. Each component points to an important set of variables that the literature suggests may be relevant to a particular case of emerging open data impact.

This operational framework initially started with 'national context' at the top, supported by a tool outlining a series of six dimensions of national setting that researchers were encouraged to focus upon (political, social, economic, organisational, legal and technical), and then five subsequent components read clockwise and broadly understood as elements that could be treated sequentially, building up a case study. However, when the case studies reported their initial findings in a workshop in mid-2014 in Berlin participants identified the importance of placing the specific 'locality, sector or issue' at the top of the model, emphasising the importance of this to any understanding of open data impacts. This component was also retitled from its earlier label of 'governance setting', to better capture the range of ways on which cases approached this important issue of defining a particular information polity. The other components were re-ordered to their arrangement in the diagram above - where rather than supporting the linear construction of cases, they are understood as interconnected, and to be approached iteratively, looking back and forwards between specific issues and national context, technical standards and use of data, or intermediary actions and data users.

The scope of each resulting framework element can be described as follows:

- Locality, sector or issue - including a description and history of the issues in focus, details of key stakeholders, and analysis of how data currently plays a potential role in this setting.

- The wider (national) context for open data - including descriptions of the political, organisational, legal, technical, social and economic context.

- The supply and openness of data - including an assessment of data availability, legal frameworks for data, data licenses, and the stakeholders involved in providing data.

- Technical platforms and standards - including data formats and data standards use, and any data catalogues, APIs or analysis tools provided by an open data initiative.

- Data uses and impacts - documenting the experience of those seeking to use data, and providing evidence of intended or unintended consequences.

- Intermediaries and data flow - documenting the means by which data is made accessible in the governance setting: how, and by whom?

These case components were not designed to be tightly prescriptive, or to suggest that all must be covered in the same level of depth in any research into open data. However, in the ODDC project, all cases were encouraged to address each to some degree (Davies, Perini, \& 
Alonso, 2013), and partners worked together to develop a range of common research tools to further strengthen the possibility of comparing between diverse cases.

Figure 3 summarises an output of the first project workshop in 2013, where participants identified a range of different shared methodological tools that could support cross-case sharing and learning. In particular, the use of a 10-point data checklist, based on the methodology of the Open Data Barometer (Davies, 2013c) allowed a careful distinction to be drawn between data that was accessible, but not openly licensed, and data which was accessible and legally free for re-use, but not in machine-readable forms. A number of partners also collaborated to develop contextualised 'follow the data' interviewing methodologies (Sands, Borgman, Wynholds, \& Traweek, 2012; Sapkota, 2014; Srimarga et al., 2014), which sought to move beyond simply self-reports of data-use, and to prompt interviewees to more deeply consider and explain their data use practices.

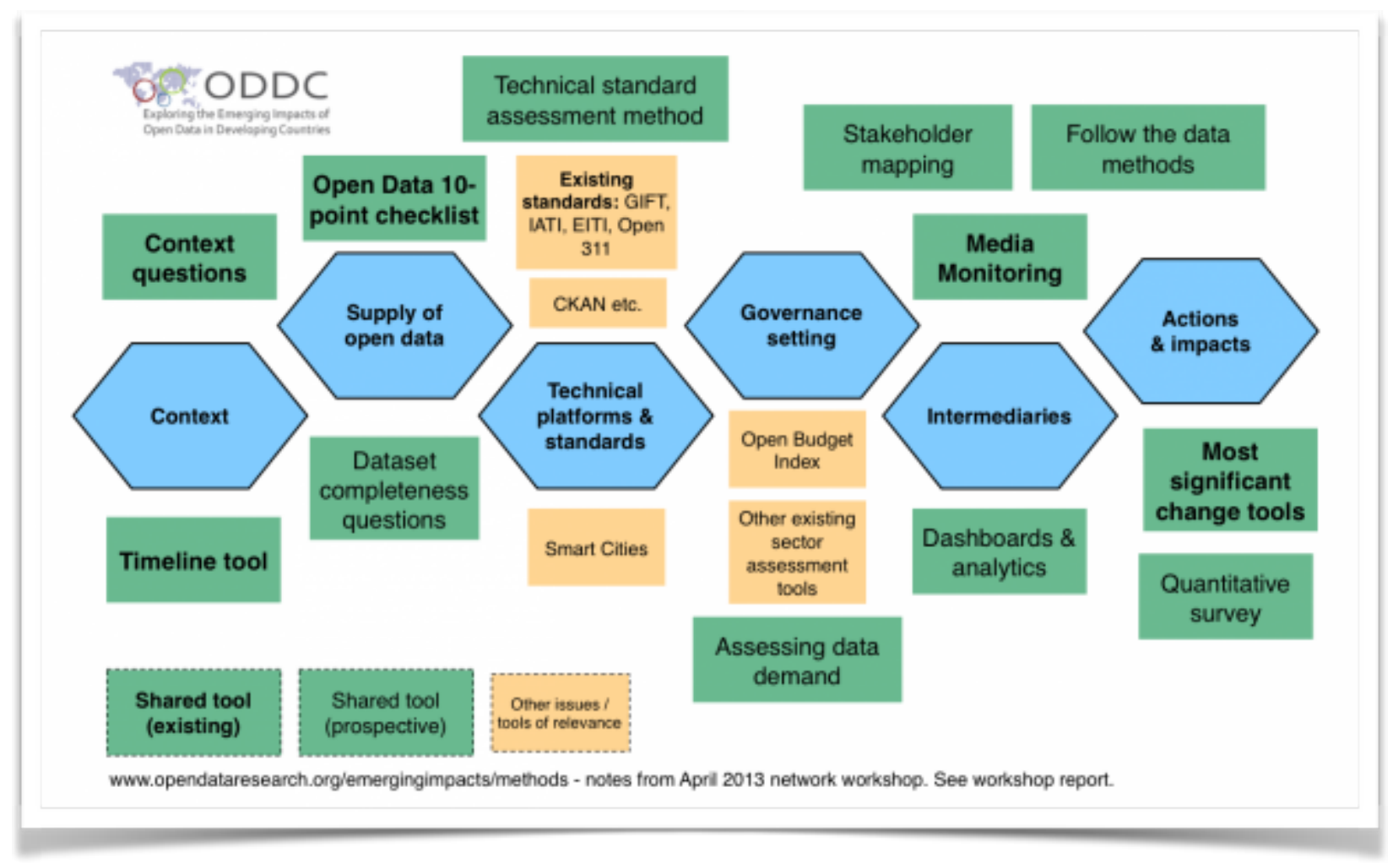

Figure 3: Mapping out methods (2013 workshop)

By working on the development of shared research tools, available to be remixed and adapted to particular uses, but remaining some common elements, we were able to move beyond an abstract conceptual framework, to have a much more applied research framework. Progress towards common tools was easier in some areas than others. For example, finding effective ways to assess the completeness of dataset, and to find a sampling frame for assessing questions around data demand, remain challenging. However, we believe that there is much value for the open data research field in refining a suite of research tools and common methods, at both the macro and case study level (see Caplan et al., 2014 for more details of ODDC project work on this topic). 


\section{Reflection: looking back and looking ahead}

In this section, we reflect on the use of the framework, and look ahead to future research priorities.

The framework was intended to support a socio-technical approach to research into emerging impacts of open data, engaging researchers from a range of disciplinary backgrounds. Project evaluation (Da Silva \& Montano, 2014), and discussion with partners in the final workshop in Berlin, has largely validated its role in doing this, although the framework has proven less effective in providing the conceptual resources for the synthesis of cross-case findings. Here, researchers have turned to theoretical constructs, such as the concept of a data ecosystem, linking synthesis of ODDC cases into a wider discourse in the open data field (Heimstadt, Saunderson, \& Heath, 2014; Helbig, Cresswell, Burke, \& Luna-reyes, 2012; Helbig, Cresswell, Burke, Pardo, \& Luna-Reyes, 2012; Van Schalkwyk, Willmers, \& McNaughton, 2015). This allowed complex relationships between elements to be alluded to, without being catalogued in detail. In some areas, the cross-case analysis has also required the deeper conceptualisation of particular terms. In particular, where our framework talks very generally of 'intermediaries', work arising from its application has pointed to the need for much clearer definition of different intermediaries and intermediary roles (Van Schalkwyk, Canares, Chattapadhyay, \& Andrason, 2015)

In the original conceptual framework report (Davies et al., 2013), we set out four priority policy and practice debates to be explored:

(1) Understanding the flow of data from open data initiatives, to potential users, through a range of technical and social intermediaries.

(2) Understanding how the wider context affects the potential of an open data initiative.

(3) Understand how global standards, platforms, infrastructure and 'eco-systems' of open data affect local contexts.

(4) Understanding the distribution of benefits from open data initiatives.

However, the findings from the studies using the framework have demonstrated to us that in setting out these focal areas, we were also still narrowing our view to a linear theory of change, which assumed a flow from data initiative to impact. Instead, researchers found that whilst the chain from data to impact is often broken by issues of poor data quality, lack of standardisation, or lack of ready intermediaries, the introduction of open data ideas through policy initiatives can create new space for two-way dialogue between civil society and government on transparency and accountability issues, and, in the right contexts, can lead to a reshaping of governments internal data practices (Beghin \& Zigoni, 2014; Davies, 2014a). Whilst the nature of the ODDC programme, with local cases, limited the extent to which global standards, platforms and infrastructures were brought into view, researchers were able to develop rich narratives about the local context of the open data initiatives they were studying, and to point, if not to distribution of benefits, to the range of actors involved in intermediary use of open data.

By looking at existing governance settings, and then exploring how open data entered into these, the framework brought into view the fact that many of the organisations who are 
potential users of open data already have well established data practices, often involving access to data through personal relationships and networks (Chattapadhyay, 2014; Sapkota, 2014; Srivastava et al., 2014). In these contexts, introducing open data may create an 'evolution' of practice, rather than 'data revolution' (Davies, 2014a), and this has consequences for how demand for open data will be clearly articulated (Canares, 2014). The central place given in the revised framework to 'locality, sector or issue' reflects a recognition that whilst open data initiatives may have many common features, they are also increasingly become adopted, and adapted, as part of wider agendas (Davies, 2014a, 2014b).

This shift, from looking at open data in the abstract, to an embedded approach to research open data to tackle the development challenges of a specific setting is key to any future research agenda. The 2015 International Open Data Conference featured 12 thematic tracks, looking at open data in broad sectors such as agriculture, justice or the environment (IDRC, 2015), and increasingly sector-specific research programmes are emerging, such as that of the Global Open Data for Agriculture and Nutrition (GODAN) network. As research goes deeper into particular localities, sectors and settings, keeping the wider components of a shared research framework in view will become increasingly important to ensure learning can be shared. Whilst in 2012, the issue of open data standards and interoperability was on our agenda, it has been perhaps the hardest theme to explore. However, with the inclusion of a principle on data 'interoperability' in the 2015 International Open Data Charter (IODC Stewards, 2015), we believe this will be an area in need of much more intensive work in the coming years, to understand how the data infrastructures now being built, sector by sector, can be an effective platform for each of the emerging outcomes sought from open data.

\section{Conclusions}

This paper has presented the ODDC framework and discussed how it differs from a supply and demand model for open data. The framework has contributed to a research agenda with a broad view of open data. As further developed in other parts of this journal, the case studies involve different kinds of data, decision-making and emerging outcomes, and respond to local policy and practice questions as well as cross-cutting research issues. The focus on case study research allowed us to understand the dynamics of particular uses of open data in influencing processes of decision-making, and allowed the identification of key contextual factors impacting upon the realisation of outcomes from open data, as well as identification of strategies and interventions employed within an open data initiative that can impact upon the quality of openness.

The post-implementation reflection on the framework reinforced the need to think about the role of openness across a wide range of data ecosystems, including data about governments and states, data about companies and markets, and aggregate data about citizens. It also reinforced the importance of starting with a specific issue, and exploring open data in specific governance setting (such as budget, procurement or transport). Based on a clear identification of the setting, it becomes more meaningful to critically articulate (and evaluate) a range of emerging outcomes from data availability, including transparency and accountability, innovation and economic growth and inclusion and empowerment (as well as identify situations where this is not the case). For instance, groups such as the Open Contract Partnership and GODAN are articulating their theories of change on the role of open data in 
public procurement and agriculture. Grounded frameworks around specific governance settings will be a key pathway for future research.

At the same time, the general framework proved to be a valuable tool to help address the constant tension in open data research: the need to balance between the specific of an issue, and a broad and global movement, which aspires for global standards and scale. With a new generation of global data initiatives currently becoming established, such as the International Open Data Charter (IODC Stewards, 2015), and work on data infrastructures to support monitoring of the Sustainable Development Goals (Data Revolution Group, 2014), there will increasingly be pressure to move beyond local experiments with open data to instead work on shared global infrastructures that can deliver key impacts around the world.

Although the ODDC project has drawn to a close, the new Open Data for Development Network (OD4D) is now building on the different clusters explored in ODDC. OD4D will refine understanding of the specific theories of change for open data to address issues relating to anti-corruption, cities, health and education ${ }^{3}$. This work will continue to build local knowledge about what works in securing emerging impacts from open data, drawing on the framework and methods presented here to support critical reflection and practical exploration of the opportunities to create new open data enabled practices.

\section{Author's note}

The work for this paper was funded by IDRC grant 107075 (idrc.ca), and co-ordinated by the World Wide Web Foundation. This paper builds upon the following project reports: Davies, T., Perini, F., \& Alonso, J. M. (2013). Researching the emerging impacts of open data ODDC conceptual framework (No. 1); and Davies, T. (2014). Open Data in Developing Countries: Summary of Emerging Insights from Phase I. Berlin, Germany.

The authors would like to thank all the participants of the initial ODDC workshop, research mentors, and members of the Open Data Research Network, to whose input this work owes considerable debt. We also thank the two anonymous reviewers whose contributions have greatly strengthened the structure and content of this paper.

\section{References}

Abdulai, E. S. (2014). Connecting Open Data and the Right to Information in Sierra Leone. Retrieved from http://www.opendataresearch.org/content/2014/642/connecting-opendata-and-right-information-sierra-leone

Agar, J. (2003). The Government Machine: A Revolutionary History of the Computer. MIT Press. Retrieved from http://www.amazon.co.uk/The-Government-MachineRevolutionary-Computing/dp/0262012022

Albano, C. S., \& Reinhard, N. (2014). Open Government Data : Facilitating and Motivating Factors for Coping with Potential Barriers in the Brazilian Context. In IFIP International Federation for Information Processing (pp. 181-193). Retrieved from http://link.springer.com/chapter/10.1007/978-3-662-44426-9_15

\footnotetext{
3 See OD4D.net for more details.
} 
Anderson, C. (2006). The Long Tail: Why the Future of Business is Selling Less of More. Hyperion.

APC, \& CIPESA. (2012). Uganda Open Government data readiness study.

Atz, U., Heath, T., \& Fawcett, J. (2015). Benchmarking Open Data Automatically (Technical Reports No. ODI-TR-2015-000). London. Retrieved from http://theodi.org/guides/ benchmarking-data-automatically

Ballingall, R. (2011). Is There a Case For Limiting Democratic Openness? Public Policy and Governance Review, 2 (2), 52-62.

Bates, J. (2012). "This is what modern deregulation looks like" : co-optation and contestation in the shaping of the UK's Open Government Data Initiative. The Journal of Community Informatics, 8 (2). Retrieved from http://ci-journal.net/index.php/ciej/ article/view/845/916

Beghin, N., \& Zigoni, C. (2014). Measuring open data's impact of Brazilian national and sub-national budget transparency websites and its impacts on people's rights. Retrieved from http://opendataresearch.org/sites/default/files/publications/ Inesc_ODDC_English.pdfinhttp://opendataresearch.org/content/2014/651/measuringopen-datas-impact-brazilian-national-and-sub-national-budget

Bentley, C. M., \& Chib, A. (2016). The Impact of Open Development Initiatives in Lower and Middle Income Countries : A Review of the Literature. Electronic Journal of Information Systems in Developing Countries, 1-21.

Boyera, S., \& Iglesias, C. (2014). Open Data in Developing Countries: State of the Art.

Canares, M. P. (2014). Opening the Local : Full Disclosure Policy and its Impact on Local Governments in the Philippines, 2007.

Caplan, R., Davies, T., Wadud, A., Verhulst, S., Alonso, J. M., \& Farhan, H. (2014). Towards common methods for assessing open data: workshop report \& draft framework. New York. Retrieved from http://opendataresearch.org/sites/default/files/posts/Common Assessment Workshop Report.pdf

Carrara, W., Chan, W. S., Fischer, S., \& Steenbergen, E. van. (2015). Creating Value through Open Data: Study on the Impact of Re-use of Public Data Resources. http://doi.org/ $10.2759 / 328101$

Chattapadhyay, S. (2014). Opening Government Data Through Mediation: Exploring Roles, Practices and Strategies of (Potential) Intermediary Organisations in India. Retrieved from http://opendataresearch.org/sites/default/files/publications/ZB sumandro_oddc_poster_2014.07_v.2.0_small (1).pdf

Conradie, P., \& Choenni, S. (2012). Exploring Process Barriers to Release Public Sector Information in Local Government. In J. R. Gil-Garcia, N. Helbig, \& A. Ojo (Eds.), International Conference on Theory and Practice of Electronic Governance (pp. 513). New York, New York, USA: ACM. Retrieved from http://www.icegov.org/ program/icegov2012_proceedings.pdf 
Cornwall, A., \& Gaventa, J. (2001). From users and choosers to makers and shapers: repositioning participation in social policy (IDS Working Paper No. 127).

Custer, S. (2012). ICT-Enabled Citizen Feedback Loops (How To Notes). Retrieved from http://blogs.worldbank.org/ic4d/call-for-feedback-how-to-note-on-ict-enabled-citizenfeedback-loops

Da Silva, D. P., \& Montano, E. (2014). Exploring the Emerging Impacts of Open Data in Developing Countries: Research Network Outcome Evaluation Report. Retrieved from http://www.opendataresearch.org/sites/default/files/posts/ODDCoutcomeevaluation-final.pdf

Data Revolution Group. (2014). A World That Counts - Mobilising the Data Revolution for Sustainable Development, 32. Retrieved from http://www.undatarevolution.org/wpcontent/uploads/2014/12/A-World-That-Counts2.pdf

Davies, T. (2010, September 29). Open data, democracy and public sector reform: A look at open government data use from data.gov.uk. Practical Participation. Retrieved from http://www.opendataimpacts.net/report/

Davies, T. (2013a). Exploring the Emerging Impacts of Open Data in Developing Countries network meeting report: April 2013. Retrieved from http://www.opendataresearch.org/ sites/default/files/posts/ODDCNetworkWorkshop-April2013.pdf

Davies, T. (2013b). Open Data and Privacy - Discussion Notes. Retrieved from http:// www.opendataresearch.org/content/2013/501/open-data-privacy-discussion-notes

Davies, T. (2013c). Open Data Barometer - Research Handbook. Retrieved from http:// zenodo.org/record/7473

Davies, T. (2013d). Open Data Barometer: 2013 Global Report. Retrieved from http:// www.opendataresearch.org/dl/odb2013/Open-Data-Barometer-2013-GlobalReport.pdf

Davies, T. (2014a). Open Data in Developing Countries: Emerging Insights from Phase I. Berlin, Germany. Retrieved from http://opendataresearch.org/sites/default/files/ publications/Phase 1 - Synthesis - Full Report-print.pdf

Davies, T. (2014b). Open Data Policies and Practice: An International Comparison. SSRN Electronic Journal. http://doi.org/10.2139/ssrn.2492520

Davies, T., Perini, F., \& Alonso, J. M. (2013). Researching the emerging impacts of open data ODDC conceptual framework (ODDC Working Papers No. 1). Retrieved from http:// www.opendataresearch.org/sites/default/files/posts/Researching the emerging impacts of open data.pdf

De Boer, V., De Leenheer, P., Bon, A., Gyan, N. B., Van Aart, C., Gueret, C., ... Akkermans, H. (2012). RadioMarche: Distributed Voice- and Web-interfaced Market Information Systems under Rural Conditions. Lecture Notes in Computer Science, 7328. 
Dekkers, M., Poleman, F., Te Velde, R., \& De Vries, M. (2006). MEPSIR Study - 2006. Retrieved from http://ec.europa.eu/information_society/policy/psi/actions_eu/ policy_actions/mepsir/index_en.htm

Dos Santos Brito, K., Da Silva Costa, M. A., Garcia, V. C., \& De Lemos Meira, S. R. (2014). Brazilian government open data: Implementation, Challenges, and Potential Opportunities. Proceedings of the 15th Annual International Conference on Digital Government Research - Dg.o '14, 11-16. http://doi.org/10.1145/2612733.2612770

Dumpawar, S. (2015). Open Government Data Intermediaries: Mediating Data to Drive Changes in the Built Environment. MIT.

Dunleavy, P., Margetts, H., Bastow, S., \& Tinkler, J. (2006). New Public Management Is Dead-Long Live Digital-Era Governance. Journal of Public Administration Research and Theory, 16 (3), 467. http://doi.org/10.1093/jopart/mui057

EITI International Secretariat. (2012). Development of an EITI Data Standard. Retrieved from http://eiti.org/files/SWG/Background Paper - Development of an EITI Data Standard_final.pdf

Fink, K., \& Anderson, C. W. (2014). Data Journalism in the United States. Journalism Studies, (February 2015), 1-15. http://doi.org/10.1080/1461670X.2014.939852

Fioretti, M. (2010). Open Data, Open Society: a research project about openness of public data in EU local administration. Work. Pisa. Retrieved from http://www.dime-eu.org/ files/active/0/ODOS_report_1.pdf

Floridi, L. (2014). Open data, data protection, and group privacy. Philosophy \& Technology VO - 27, (1), 1. http://doi.org/10.1007/s13347-014-0157-8

Foti, J. (2015). Independent Reporting Mechanism: Technical Paper 1. Retrieved from http:// www.ncbi.nlm.nih.gov/pubmed/19623112

Fox, J. (2007). The Uncertain Relationship between Transparency and Accountability. Development in Practice, 17(4/5), 663-671. http://doi.org/ 10.1080/09614520701469955

Frank, M., \& Waddell, P. (2014). Solving the Democratic Deficit: The Role of Open Data and Intermediaries. In Conference for E-Democracy and Open Governement. Krems, Austria. Retrieved from http://duweb.donau-uni.ac.at/imperia/md/content/department/ gpa/zeg/bilder/cedem/cedem14/cedem14_proceedings.pdf\#page $=488$

Fumega, S. (2015). Understanding Two Mechanisms For Accessing Government Information And Data Around The World.

Fung, A., Graham, M., \& Weil, D. (2007). Full Disclosure: The Perils and Promise of Transparency (1st ed.). Cambridge University Press.

Fung, A., \& Weil, D. (2010). Open Government and Open Society. In D. Lathrop \& L. Ruma (Eds.), (1st ed.). O’Reilly Media.

Gerunov, A. (2015). Open Data: Policy and Implementation in Bulgaria (MRPA Paper No. 68799). Retrieved from http://econpapers.repec.org/scripts/redir.pf?u=https:// 
mpra.ub.uni-muenchen.de/68799/1/MPRA_paper_68799.pdf;h=repec:pra:mprapa: 68799

Gigler, B.-S., Custer, S., \& Bailur, S. (2014). Closing the Feedback Loop: Can Technology Amplify Citizen Voices.

Gitelman, L. (2013). “Raw Data” Is an Oxymoron. The MIT Press.

Global Integrity. (2012). So What's In Those OGP Action Plans, Anyway? Retrieved from http://globalintegrity.org/blog/whats-in-OGP-action-plans

Gray, J., Chambers, L., \& Bounegru, L. (2012). The Data Journalism Handbook. O'Reilly Media, Inc. Retrieved from http://datajournalismhandbook.org/

Gray, J., \& Davies, T. (2015). Fighting Phantom Firms in the UK : From Opening Up Datasets to Reshaping Data Infrastructures?

Grewal, A., Iglesias, C., Alonso, J. M., Boyera, S., \& Bratt, S. (2011). Open Government Data - Feasibility Study in Ghana. Retrieved from http://public.webfoundation.org/ 2011/02/OGD_chile_PR.pdf

Gurin, J. (2014). Open Data Now. Open Data Now.

Gurin, J., \& Manley, L. (2015). Open Data for Sustainable Development.

Gurstein, M. (2011). Open data: Empowering the empowered or effective data use for everyone? First Monday, 16 (2). Retrieved from http://firstmonday.org/htbin/cgiwrap/ bin/ojs/index.php/fm/article/view/3316/2764

Heald, D. (2006). Varieties of Transparency. Proceedings of the British Academy, 135, 25-43.

Heald, D. (2011). When Transparency meets Surveillance: External Monitoring of Country Public Finances. In 1st Global Conference on Transparency Research (pp. 19-20). Newark, New Jersey. Retrieved from http://spaa.newark.rutgers.edu/home/ conferences/ 1 stgctr/papers.html

Heimstadt, M., Saunderson, F., \& Heath, T. (2014). Conceptualizing Open Data ecosystems: A timeline analysis of Open Data development in the UK.

Helbig, N., Cresswell, A. M., Burke, G. B., \& Luna-reyes, L. (2012). The Dynamics of Opening Government Data, 1-34. Retrieved from http://www.ctg.albany.edu/ publications/reports/opendata/opendata.pdf

Helbig, N., Cresswell, A. M., Burke, G. B., Pardo, T. A., \& Luna-Reyes, L. (2012). Modelling the Informational Relationships between Government and Society: A Pre-Workshop White Paper (Open Government Consultative Workshop). New York.

Heusser, F. I. (2012). Understanding Open Government Data and addressing its Impact.

HM Government. (2012a). Open Data White Paper: Unleashing the Potential. London, UK: HM Government. 
HM Government (2012). Protection of Freedoms Act 2012. United Kingdom: Queen's Printer of Acts of Parliament. Retrieved from http://www.legislation.gov.uk/ukpga/2012/9/ part/6/enacted

Hogge, B. (2010). Open Data Study (Transparency and Accountability Initiative). Transparency and Accountability Initiative. Transparency and Accountability Initiative. Retrieved from http://www.transparency-initiative.org/wp-content/uploads/ 2011/05/open_data_study_final.pdf

Hood, C. C., \& Margetts, H. Z. (2007). The Tools of Government in the Digital Age: Second Edition (2nd ed.). Palgrave Macmillan.

Hossain, M. A., Dwivedi, Y. K., \& Rana, N. P. (2015). State of the Art in Open Data Research: Insights from Existing Literature and a Research Agenda. Journal of Organizational Computing and Electronic Commerce, 9392(December), 10919392.2015.1124007. http://doi.org/10.1080/10919392.2015.1124007

Howard, A. B. (2014). The Art and Science of Data-Driven Journalism. Retrieved from http://towcenter.org/wp-content/uploads/2014/05/Tow-Center-Data-DrivenJournalism.pdf

Huber, S., \& Maier-Rabler, U. (2012). The changing roles of citizens, civil society and public authority in Open Government. In XXIInd World Congress of Political Science (pp. 1-17). Retrieved from http://paperroom.ipsa.org/papers/paper_11202.pdf

IDRC. (2015). Enabling the Data Revolution: An International Open Data Roadmap. Retrieved from http://www.opendatacon.org/report/

Iglesias, C. (2011). Open Government Data - Feasability Study in Chile (Draft). Retrieved from http://public.webfoundation.org/2011/02/OGD_chile_PR.pdf

IODC Stewards. (2015). International Open Data Charter. Retrieved from http:// opendatacharter.net/

Janssen, K. (2012). Open Government Data and the Right to Information: Opportunities and Obstacles. The Journal of Community Informatics, 8 (2). Retrieved from http://cijournal.net/index.php/ciej/article/view/952/954

Janssen, M., Charalabidis, Y., \& Zuiderwijk, A. (2012). Benefits, Adoption Barriers and Myths of Open Data and Open Government. Information Systems Management, 29 (4), 258-268. http://doi.org/10.1080/10580530.2012.716740

Joshi, A. (2012). Do They Work? Assessing the Impact of Transparency and Accountability Initiatives in Service Delivery. Tbc. Retrieved from http://www.dfid.gov.uk/R4D/ Output/188642/Default.aspx

Khan, S., \& Foti, J. (2015). Aligning supply and demand for better governance: open data in the open government partnership. Retrieved from http://www.opendataresearch.org/ dl/symposium2015/odrs2015-paper49.pdf 
Kuk, G., \& Davies, T. (2011). The Roles of Agency and Artifacts in Assembling Open Data Complementarities. In Thirty Second International Conference on Information Systems. Retrieved from http://eprints.soton.ac.uk/273064/

Kulk, S., \& Van Loenen, B. (2012). Brave New Open Data World? International Journal of Spatial Data Infrastructures Research, 7, 196-206. http://doi.org/ 10.2902/1725-0463.2012.07.art10

Kundra, V. (2012). Digital Fuel of the 21st Century: Innovation through Open Data and the Network Effect (Discussion Paper Series No. 70). Public Policy. Cambridge, Mass.

Kuriyan, R., Bailur, S., Gigler, B.-S., \& Park, K. R. (2012). Technologies for Transparency and Accountability (Open Development Technology Alliance). Washington DC.

Lathrop, D., \& Ruma, L. (2010). Open Government: Collaboration, Transparency, and Participation in Practice. O'Reilly Media.

Lee, S. S. (2014). Open Financial Data: Demand, Capacity, and Citizen Engagement in Online and Offline Communities.

Lessig, L. (2009, October). Against Transparency. The New Republic. Retrieved from http:// www.tnr.com/article/books-and-arts/against-transparency

Magalhaes, G., Roseira, C., \& Strover, S. (2013). Open government data intermediaries: a terminology framework. In Proceedings of the 7th International Conference on Theory and Practice of Electronic Governance (pp. 23-26). Seoul, Republic of Korea: ACM Press. Retrieved from http://dl.acm.org/citation.cfm?id=2591947

Maguire, S. (2011). Can Data Deliver Better Government? The Political Quarterly, 82 (4). http://doi.org/10.1111/j.1467-923X.2011.02249.x

Majeed, R. (2012). Disseminating the power of information - Kenya Open Data Initiative, 2011 - 2012 (Innovations for Successful Societies). Retrieved from http:// www.princeton.edu/successfulsocieties/content/superfocusareas/traps/ME/ policynotes/view.xml?id=206

Manyika, J., Chui, M., Groves, P., Farrell, D., Van Kuiken, S., \& Doshi, E. A. (2013). Open data : Unlocking innovation and performance with liquid information.

Martin, C. (2014). Barriers to the Open Government Data Agenda: Taking a Multi-Level Perspective, 6 (3), 217-240.

Martin, S., Foulonneau, M., Turki, S., Ihadjadene, M., Paris, U., \& Tudor, P. R. C. H. (2013). Risk Analysis to Overcome Barriers to Open Data. Electronic Journal of EGovernment, 11 (1), 348-359. Retrieved from http://www.ejeg.com/issue/ download.html?idArticle $=296$

Martinisi, A. (2013). Data Journalism and Its Role in Open Government. In 5th International Scientific Conference "e-Governance” (pp. 91-98). Sofia, Bulgaria: TU Sofia, Centre for E-Governance. Retrieved from http://papers.ssrn.com/sol3/papers.cfm? abstract_id $=2328065$ 
Mayo, E., \& Steinberg, T. (2007). Power of Information Review. Retrieved from http:// www.cabinetoffice.gov.uk/reports/power_of_information.aspx

McClean, T. (2011). Not with a Bang but a Whimper: The Politics of Accountability and Open Data in the UK (APSA 2011 Annual Meeting Paper).

McGee, R., \& Edwards, D. (2016). Opening Governance - Change, Continuity and Conceptual Ambiguity. IDS Bulletin, 47(1), 1-22. http://doi.org/ 10.19088/1968-2016.103

McGee, R., Edwards, D., Minkley, G., Pegus, C.-M., \& Brock, K. (2015). Making All Voices Count Research and Evidence Strategy.

Meijer, A. J. (2007). Publishing public performance results on the Internet. Government Information Quarterly, 24 (1), 165-185. http://doi.org/10.1016/j.giq.2006.01.014

Melamed, C. (2014). A World That Counts: Mobilisation the Data Revolution for Sustainable Development. New York. Retrieved from http://www.undatarevolution.org/wpcontent/uploads/2014/12/A-World-That-Counts2.pdf

Moss, G., \& Coleman, S. (2014). Deliberative manoeuvres in the digital darkness: EDemocracy policy in the UK. British Journal of Politics and International Relations, 16, 410-427. http://doi.org/10.1111/1467-856X.12004

Murray, A. (2011). Transparency, Scrutiny and Responsiveness: Fashioning a Private Space within the Information Society. The Political Quarterly, 82 (4), 509-514. http:// doi.org/10.1111/j.1467-923X.2011.02245.x

Newbery, D., Bently, L., \& Pollock, R. (2008). Models of public sector information provision via trading funds.

Nichols, R. (2010). Do apps for democracy and other contests create sustainable applications. Retrieved March 6, 2013, from http://www.govtech.com/e-government/ Do-Apps-for-Democracy-and-Other.html?page=1

O'Reilly, T. (2010). Government as a platform. In D. Lathrop \& L. Ruma (Eds.), (1st ed.). O’Reilly Media. Retrieved from http://chimera.labs.oreilly.com/books/ 1234000000774/ch02.html

Open Knolwedge Foundation (2011). Beyond Access : Open Government Data \& the Right to (Re) use Public Information. Madrid. Retrieved from http://www.access-info.org/ documents/Access_Docs/Advancing/Beyond_Access_7_January_2011_web.pdf

Open Knowledge Foundation. (2014). The Open Definition - Version 2.0. Retrieved February 2, 2015, from http://opendefinition.org/

Perini, F., Davies, T \& Alonso, J. (2012). Workshop report: Fostering a Critical Development Perspective on Open Government Data. Brasilia. Retrieved from http:// www.opendataresearch.org/post/23536123039/odrbrasilia

Pollock, R. (2009). The Economics of Public Sector Information (Cambridge Working Papers in Economics). Retrieved from http://econpapers.repec.org/paper/camcamdae/ 0920.htm 
Powell, M., Davies, T., \& Taylor, K. C. (2012). ICT for or against development? An introduction to the ongoing case of Web3. Retrieved from http:// wiki.ikmemergent.net/files/1204-IKM-Working_Paper_16-WEB3-Mar_2012-2.pdf

Power, T. J., \& Taylor, M. M. (2011). Corruption and Democracy in Brazil: The struggle for accountability. University of Notre Dame.

Rahemtulla, H., Custer, S., Tisacova, I., Jhalla, K., Gigler, B.-S., \& Brigham, C. (2012). The Journey of Open Government and Open Data Moldova.

Rahemtulla, H., Kaplan, J., Gigler, B.-S., Cluster, S., Kiess, J., \& Brigham, C. (2011). Open Data Kenya: Case study of the Underlying Drivers, Principal Objectives and Evalution of one of the first Open Data Initiatives in Africa (Abridged Version) DRAFT.

Reiche, K. J., Höfig, E., \& Schieferdecker, I. (2014). Assessment and Visualization of Metadata Quality for Open Government Data. Proceedings of the 4th Conference for E-Democracy and Open Government (CeDEM 2014), 1, 335-346.

Robinson, D. G., Yu, H., Zeller, W., \& Felten, E. (2009). Government data and the invisible hand. Yale Journal of Law \& Technology, 160, 160-175. Retrieved from http:// papers.ssrn.com/sol3/papers.cfm?abstract_id $=1138083$

Rojas, F. M. (2012). Transit Transparency: Effective Disclosure through Open Data. Retrieved from http://www.transparencypolicy.net/assets/ FINAL_UTC_TransitTransparency_8 28 2012.pdf

Roy, J. (2014). Open Data and Open Governance in Canada: A Critical Examination of New Opportunities and Old Tensions. Future Internet, 6 (3), 414-432. http://doi.org/ $10.3390 /$ fi6030414

Rumbul, R. (2015). Who benefits from civic technology? Retrieved from https:// www.mysociety.org/files/2015/10/demographics-report.pdf

Sands, A., Borgman, C., Wynholds, L., \& Traweek, S. (2012). Follow the Data: How astronomers use and reuse data. In ASIST 2012. Baltimore, MD, USA. Retrieved from http://asis.org/asist2012/proceedings/Submissions/341.pdf

Sapkota, K. (2014). Exploring the Impacts of Open Aid Data and Budget Data in Nepal. Retrieved from http://www.opendataresearch.org/sites/default/files/publications/Open Aid and Budget Data in Nepal - 15th Sept-print.pdf

Scassa, T. (2014). Privacy and Open Government. Future Internet, 6 (2), 397-413. http:// doi.org/10.3390/fi6020397

Shemie, D., Hirn, M., Raman, V., Paradi-Guildford, C., Sabet, E., Simon, Y., ... Anderson, E. (2012). Water Hackathon: Lessons Learned (Water Papers). Washington DC.

Smith, M. L. (2015). Being Open in ICT4D. 13th International Conference on Social Implications of Computers in Developing Countries. Negombo, Sri Lanka. Retrieved from http://papers.ssrn.com/sol3/papers.cfm?abstract_id=2526515 
Smith, M. L., \& Reilly, K. M. A. (2013a). Open Development: Networked Innovations in International Development. (M. L. Smith \& K. M. A. Reilly, Eds.) (Vol. 13). MIT Press. http://doi.org/10.1596/1020-797X_13_2_14

Smith, M. L., \& Reilly, K. M. A. (2013b). The Emergence of Open Development in a Network Society. In M. L. Smith \& K. M. A. Reilly (Eds.), Open Development: Networked Innovations in International Development. MIT Press.

Speck, B. (2011). Audit Institions. In T. J. Power \& M. M. Taylor (Eds.), Corruption and Democracy in Brazil: the struggle for accountability. University of Notre Dame.

Srimarga, I. C., Suhaemi, A. M., Narhetali, E., Wahyuni, I. N., Rendra, M., Firmansyah, S., ... Heriyanto, W. (2014). Open Data Initiative of Ministry of Finance on National Budget Transparency in Indonesia. Retrieved from http://www.opendataresearch.org/ content/2014/697/open-data-initiative-ministry-finance-national-budget-transparencyindonesia

Srinivasan, S. (2012). Mapping the Tso Kar basin in Ladakh. The Journal of Community Informatics, 8 (2). Retrieved from http://ci-journal.net/index.php/ciej/article/view/ $891 / 919$

Srivastava, N., Agarwal, V., Bhattacharjya, S., Gopalakrishnan, T., Meenawat, H., Nayak, B. P., \& Soni, A. (2014). Open government data for regulation of energy resources in India. Retrieved from http://opendataresearch.org/content/2014/669/opengovernment-data-regulation-energy-resources-india

Stott, A. (2014). Open Data for Economic Growth. Washington DC. Retrieved from http:// www.worldbank.org/content/dam/Worldbank/document/Open-Data-for-EconomicGrowth.pdf

Taggart, C. (2012). The Closed World of Company Data: An examination of how open company data is in Open Government Partnership countries. Retrieved from http:// opencorporates.com/downloads/ogp_company_data_report.pdf

Tygel, A. F., Campos, M. L. M., \& De Alvear, C. A. S. (2015). Teaching Open Data for Social Movements - a Research Strategy. The Journal of Community Informatics. Retrieved from http://ci-journal.net/index.php/ciej/article/view/1220/1165

Uhlir, P. (2009). The Socioeconomic Effects of Public Sector Information on Digital Networks: Toward a Better Understanding of Different Access and Reuse Policies: Workshop Summary. Washington, D.C.: National Academies Press. Retrieved from http://www.nap.edu/catalog.php?record_id=12687

United Nations. (2010). United Nations E-Government Survey 2010: Leveraging egovenrment at a time of financial and economic crisis. United Nations.

Van den Broek, T., Rijken, M., \& Van Oort, S. (2012). Towards Open Development Data (TNO Whitepaper No. P10098). Delft. Retrieved from http://openforchange.info/ content/towards-open-development-data 
Van Schalkwyk, F., Canares, M. P., Chattapadhyay, S., \& Andrason, A. (2015). Open Data Intermediaries in Developing Countries. The Journal of Community Informatics, 12 (2).

Van Schalkwyk, F., Willmers, M., \& McNaughton, M. (2015). Viscous Open Data: The roles of intermediaries in an open data ecosystem. Journal of Information Technologies for Development, 1102(Special Issue). http://doi.org/10.1080/02681102.2015.1081868

Veljković, N., Bogdanović-Dinić, S., \& Stoimenov, L. (2014). Benchmarking open government: An open data perspective. Government Information Quarterly, 31 (2), 278-290. http://doi.org/10.1016/j.giq.2013.10.011

Von Hippel, E. (2005). Democratizing innovation. the MIT Press.

Von Hippel, E., \& Von Krogh, G. (2009). Open Source Software and the "Private-Collective" Innovation Model: Issues for Organization Science (MIT Sloan Research Papers No. 4739-09). SSRN eLibrary. MIT Sloan Research Papers. Retrieved from http:// ssrn.com/paper $=1410789$

World Bank. (2012). Project paper on a proposed additional credit to the Republic of Kenya for a Kenya Transparency and Communications Infrastructure Project. Retrieved from http://www-wds.worldbank.org/external/default/WDSContentServer/WDSP/IB/ $2012 / 03 / 12 / 000356161$ _20120312004241/Rendered/PDF/ 670650PJPR0P120Official0Use0Only090.pdf

World Resources Institute. (2012). Access to Information and Open Data Portals in Africa, pp. 1-13.

World Wide Web Foundation. (2015). Open Data Barometer: Second Edition. Retrieved from http://www.opendatabarometer.org

Worthy, B. (2013). David Cameron's Transparency Revolution? Retrieved from http:// papers.ssrn.com/sol3/papers.cfm?abstract_id $=2361428$

Wright, G., Prakesh, P., Abraham, S., \& Shah, N. (2011). Report on Open Government Data in India. Retrieved from http://www.cis-india.org/advocacy/openness/ogd-report

Zuiderwijk, A., \& Janssen, M. (2013). Open data policies, their implementation and impact: A framework for comparison. Government Information Quarterly. http://doi.org/ 10.1016/j.giq.2013.04.003 Reichman, O. J., Jones, M. B., \& Schildhauer, M. P. (2011). Como siempre, APA con todos sus manias y vainas. Science (New York, N.Y.), 331(6018), 703-5. doi:10.1126/science.1197962 